JOSEPHO. BAYLEN

\title{
GEORGE BERNARD SHAW AND THE SOCIALIST LEAGUE. SOME UNPUBLISHED LETTERS
}

When H. M. Hyndman's contentious and authoritarian leadership of the British Social Democratic Federation provoked William Morris and nine other members of its Executive Council to resign on December $24, r 884,{ }^{1}$ the Federation not only lost an important segment of its strength, but also some of its most effective members. With Morris went Dr. Edward Aveling and Eleanor Marx Aveling, Belfort Bax (the confidant of Engels), Samuel Mainwaring (a leader of the Labour Emancipation League), John Lincoln Mahon (the founder, with Andreas Scheu, of the Scottish Land and Labour League), Robert Banner (with the very active Woolwich branch of the Federation), W. J. Clark, I. Cooper, and Joseph Lane. On December 30, less than a week after the secession of this group, Morris and his colleagues formed the Socialist League which almost immediately threatened to become a most formidable competitor of the S.D.F. ${ }^{2}$ From its headquarters in a Farringdon Street loft at the edge of East London, the Socialist League issued its periodical, The Commnoweal, ${ }^{3}$ and sallied forth to realize William Morris's hope of educating the masses for "the great and inevitable change" in British political, economic, and social life. ${ }^{4}$

In its attempts to educate the working class in Socialism, the Socialist League was able to enlist the aid of several members of the Fabian Society which, by January, 1886 , had also virtually severed its ties with the S.D.F. ${ }^{5}$ But the co-operation of such Fabians as George Bernard Shaw was more the result of the respect and affection which

${ }^{1}$ Henry Pelling, The Origins of the Labour Party, 1880-1900 (London 1954), p. 30; Chushichi Tsuzuki, H. M. Hyndman and British Socialism (Oxford i 961), p. 66; May Morris, William Morris, Artist, Writer, Socialist (Oxford r 936), II, chap. 7.

2 Tsuzuki, p. 67; Pelling, p. 31 ; E. P. Thompson, William Morris. Romantic to Revolutionary (London 1955), p. 427.

3 Pelling, p. 34; Lloyd Wendell Eshleman, A Victorian Rebel. The Life of William Morris (New York 1940), p. 248.

4 Pelling, p. 32.

5 Cf. Tsuzuki, p. 72 ; Eshleman, p. 228. 
Morris's humanity and warm personality inspired and a mutual conviction that education and organization must precede any radical alteration of the structure of society, than any agreement with Morris's rejection of Parliamentary action or compromise on the part of Socialists. ${ }^{1}$ Indeed, it was over this issue, as well as the Socialist League's failure to attract widespread public support and inability to remedy its organizational defects, that the League finally split and collapsed at the end of the decade. ${ }^{2}$ Yet, before its demise in I 888, the League achieved some gratifying successes in its endeavours to interest the British proletariat in the general principles of Socialism.

If the Socialist League was successful in its propaganda, especially during the first two years of its life, $188,-86$, this success was in no small measure due to the work of George Bernard Shaw. ${ }^{3}$ He was certainly "one of the most brilliant of the open-air propagandists" for the League even though he persistently refused to become a member of the organization on the grounds that he felt more at home in the middle-class milieu of Fabianism. ${ }^{4}$ In spite of Morris's disappointment with the refusal of Shaw to stand by the League in such matters as the League's challenge to debate Charles Bradlaugh over the latter's denunciation of Socialism, Morris respected Shaw's independence and keen intellect. ${ }^{5}$ On the part of Shaw, he found it difficult to resist the magnetism of Morris's personality and readily acknowledged that even though they were on many issues at opposite poles of the Socialist spectrum Morris was the nexus which bound him to the Socialist League. ${ }^{6}$ Then, too, young Shaw, still an unknown beginning his career as a reviewer of books for the Pall Mall Gazette, appreciated Morris's encouragement and recognition of his talents. However, although Shaw understood the virtues and defects of Morris's Socialism, Morris failed to fully comprehend the wellsprings and limitations of Shaw's affinity for Socialism.

In his perceptive analysis of Shaw's Socialism, E. J. Hobsbawm

${ }^{1}$ Eshleman, pp. 23 I, 248; Pelling, p. 33 ; Archibald Henderson, Bernard Shaw. Playboy and Prophet (New York 1932), p. I95; see also Shaw's introduction in May Morris, II, xix; and Bernard Shaw, William Morris as I Knew Him (New York I936), pp. I 2-I 4.

2 Tsuzuki, pp. 67-68; Pelling, pp. 32-33.

3 Thompson, pp. 466, 584-85,601.

4 Ibid., pp. 466, $584-85$.

5 Ibid., p. $585 \& \mathrm{n}$.

6 See Shaw in May Morris, II, xix; Shaw, William Morris, p. I9; Henderson, Shaw. Playboy and Prophet, p. I95.

7 Cf. Dan H. Laurence, G.B.S. and the Gazette: A Bibliographical Study, in:. The Shaw Review, III (Sept. 1960), pp. 20-26; Patrick G. Hogan, Jr. and Joseph O. Baylen, G. Bernard Shaw and W. T. Stead: An Unexplored Relationship, in: Studies in English Literature, I 500-1900 [Rice University], I (Autumn, 1961), pp. 123-26. 
drew attention to the role of Shaw's Irish background and his "acute consciousness of being declassed". Perhaps most important to Hobsbawm was the fact that Shaw's attraction to Socialism reflected "the newly aroused guilty conscience of the British middle class" during the later Victorian period. ${ }^{1}$ Elements of artistic and emotional discontent made Shaw a rebel and led him, like Morris and other Victorian intellectuals, "to work actively for complete social revolution." Moreover, added Hobsbawm,

"like most other intellectuals [of his time], whose mental background had hitherto been that of left-wing liberalism, [Shaw] also found himself approaching Socialism by way of a logical extension of the doctrines of middle-class radicalism ... [Like others] who had pushed the Orthodox radical critique of society to its uttermost limits and wanted to push beyond, Shaw became a Marxist, Marxism being then the only effective Socialism on the horizon ..."2

Still, Shaw was not a Marxist "in the present sense" of the word and, in the opinion of Hobsbawm, never became even a "near-Marxist revolutionary" like Morris. He was merely a rebel with "a socialist theory, to which he devoted a lifetime of active political work - almost full-time work for long periods in the [eighteen-] eighties, unpaid, unadvertised and devoted ..."3 When, during the heyday of the Socialist League from $\mathrm{I} 88$; to 1888 , "the formation of an openly reformist, gradualist wing [among the British Socialists] took place", Shaw identified himself with the "reformists" and, unlike Morris, "became for two generations the chief public champion of the most right-wing of the moderates; and, moreover, the one which gloried in accepting current bourgeois orthodoxy on as many points as it could."4 As a middle-class Socialist, Shaw and other Fabians resented being completely identified with the proletariat. ${ }^{5}$ It was largely for this reason that when the Socialist League presumed to address him as "comrade" he hastened to reprove its current secretary with the

${ }^{1}$ E. J. Hobsbawm, Bernard Shaw's Socialism, in: Science and Society, XI (Fall, 1947), p. 307. This study is undoubtedly the most able analysis of Shaw's Socialist theory and practice.

2 Ibid., p. 308. In this direction, see also Joseph O. Baylen and Patrick G. Hogan, Jr., G. B. Shaw's Advice to W. T. Stead on the "New Journalism", in: Journalism Quarterly, XXXIX (Winter, 1962), pp. 190-91.

${ }^{3}$ Hobsbawm, pp. 308, 3 I0.

4 Ibid., pp. 3 I IO-I I.

5 Ibid., Pp. 3 I I-I 2. 
statement: "I am G. Bernard Shaw of the Fabian Society, member of an individualist state, and therefore nobody's comrade."1

The following communications which Shaw addressed to the Secretaries of the Socialist League from January 20 , I885 to October 26, 1887 not only help to chronicle Shaw's work with the League and reflect something of the Shavian wit and style which mark the productions of his maturity, but alse contribute to an understanding of the personality and Socialism of Shaw at the beginning of his career. ${ }^{2}$ In a sense, Shaw's last two post cards in 1887 signal the "recession" in the Victorian intellectuals' Socialism which was soon to come with the "Bloody Sunday" riot of November 13, I887 in Trafalgar Square." It was an event which contributed to the destruction of the Socialist League and confirmed Shaw's lack of faith in that which the League embraced as a truism - the revolutionary possibilities of the working class. ${ }^{4}$

\section{[Shaw to J. L. Mahon] ${ }^{5}$}

\section{Dear Mahon}

36 Osnaburgh St. N.W. 2oth January, i 885

\section{Tomorrow (Wednesday) I am going to talk to the Dialectical}

1 Shaw to J. L. Mahon, April 13, 1889. The Socialist League Archive, International Institute of Social History, Amsterdam.

2 I am indebted to Professor Dr. A. J. C. Rüter, Director of the International Institute of Social History, and the Public Trustee and The Society of Authors in London for permission to edit and publish the correspondence of George Bernard Shaw in the Socialist League Archive in the possession of the International Institute of Social History in Amsterdam. I am also grateful to Miss J. Dommisse and Mr. F. Kool of the Institute for advice and suggestions rendered in the process of preparing the Shaw correspondence for publication.

3 Hobsbawm, pp. 3I 2-13; see also S. Maccoby, English Radicalism, I886-19 I4 (London 1953), pp. 40-4I \& n.

4 Hobsbawm, p. 3 г2.

5 John Lincoln Mahon, a young engineer of Irish origin, was noted as a somewhat erratic zealot in the Socialist movement and a skilled open-air speaker. In I884, he abandoned engineering to establish a shortlived publishing house for the production of "advanced" Socialist literature. After the failure of this venture in August, 1884 , he became a "floating agitator" in Socialist circles preaching that the possession of property was the absolute key to political power. With Andreas Scheu, Mahon founded the Scottish Land and Labour League to promote Socialism in Scotland and the North of England, and although the Scottish League affiliated with the Social Democratic Federation, Mahon was highly critical of the Federation's programme. He was a member of the cabal which challenged Hyndman's leadership in the S.D.F. and joined William Morris in seceding from the Federation. As one of the founders of the Socialist League, Mahon became its first Secretary. Thompson, pp. 405-06, 412, 512 ; Tsuzuki, pp. 57, 82. 
Society about Socialism at Anderton's Hotel..$^{6}$ I intend to give them specimens of manifestoes, ${ }^{2}$ and if you could send me fifty copies of yours by an early post, so that they may arrive here before seven o'clock, I can distribute thern with the rest. I should have written sooner, but have not had time to think about the lecture this evening.

Yours faithfully

George Bernard Shaw

[Post card]

The Secy

Socialist League
[Shaw to Mahon]

36 Osnaburgh St. N.W. I 9 th March I 88 s

Kindly remind the Woolwich branch that I have not yet received from them the promised intimation of when and where $I$ am to lecture on "Civil War" next Sunday, the 22nd inst.

Yrs faithfully

George Bernard Shaw

[Post card]

J. L. Mahon

The Socialist League

27 Farringdon St. E.C.

I shall be glad to get out of Woolwich, ${ }^{3}$ as I have an alternative engagement that I want to keep if possible. Therefore do not book me for Notting Hill this time. Shall be delighted to go there on any future date, if I am free.

$$
\text { G. B. S. }
$$

1 Shaw, a member of the Malthusian and Millite Dialectical Society since 1880 , lectured to the Society on "Socialism" as scheduled. It is interesting to note that at this meeting, on January 21 , Shaw first made the acquaintance of Mrs. Annie Besant. (George Bernard Shaw Diary, Jan. 1885 - July 31, 5886 , in the British Library of Political and Economic Science, London.) I am grateful to Mr. Geoffrey Allen, the keeper of Manuscripts, and the Director of the library for permission to consult the Shaw Diaries for $1885-1897$, hereafter cited as G.B.S. Diary. On Shaw's association with the Dialectical Society, see Archibald Henderson, George Bernard Shaw: Man of the Century (New York 1956), pp. 136, 139. 2 A reference to the "Manifesto" of the Socialist League in January, 188 , calling for "a complete revolution in the basis of existing society" and the creation of a decentralized authority or a "Socialism of a Federation of Communes." Eshleman, pp. 248-49.

3 Since Shaw made no mention of a lecture at Woolwich in his diary entry for March 22, it appears that he did not fulfil this engagement. 
[Shaw to J. L. Mahon]

36 Osnaburgh St. N.W. I 3 th April, I 885

Dear Mahon - or stop a bit: this is official. Dear Sir

Your letter dated IIth inst. has just reached me. The informal consent on my part to speak at an Anti-Soudanese-War meeting, ${ }^{1}$ to which you allude, was conditional. When Mr. Scheu, ${ }^{2}$ in your presence, proposed that I should move, and he second, the first resolution, I said I would if the resolution were good enough. On the strength of this, the Socialist League have circulated a handbill containing two resolutions which I never saw, with a statement that that will be supported by "Comrade Shaw." Now, as I hate all fraternity mongering just as heartily as any other variety of cant, and as I expressly protested against and repudiated it at a former meeting of the League, I consider the action of the League in announcing me as "Comrade", as immoral in its way as the Nile expedition. I am G. Bernard Shaw of the Fabian

1 The massacre of General "Chinese" Gordon and the defenders of Khartoum in the Sudan at the hands of the Mahdi and his dervishes in late January, 1885 , had shocked the British nation and evoked a popular demand that the Gladstone Government act to avenge Gordon's death and to establish Anglo-Egyptian control over the Sudan. Gladstone had reluctantly dispatched a British force (prior to Gordon's death) which had reached Khartoum only a few days too late to save Gordon and, in response to the public demand, the Prime Minister gave the impression of making posthumous amends for what seemed to the Queen and popular opinion to have been the Government's "betrayal" of Gordon. But in March and April, Gladstone took advantage of the Penjdeh crisis with Russia to reverse his earlier policy by announcing on April I3, the abandonment of plans for the occupation of the Sudan. It was the ensuing outcry in the press and in Imperialist circles against Gladstone's reversal which Shaw and other Socialists opposed as a symptom of "the degeneracy and rottenness of British imperialism..." Hobsbawm, p. 3 I4. See also Philip Magnus, Gladstone. A Biography (London 1954), pp. 325-27; L. A. Fabunmi, The Sudan in Anglo-Egyptian Relations. A Case Study in Power Politics, 1800-1956 (London 1960), pp. 37-38, 45 .

2 Andreas Scheu (d. 1927), an Austrian furniture designer, left-wing Socialist, and friend of Engels, was forced to flee from Vienna in 1874 and settled in Edinburgh. With J. L. Mahon, Scheu established the Scottish Land and Labour League and gained some prominence in the British Socialist movement as an impassioned and fluent orator. As a close friend and collaborator of Morris, Scheu had Morris's sympathy and support in his denunciation of Hyndman's attempt to inject anti-foreign prejudice and jingoism in the S.D.F. With Morris and Joseph Lane, Scheu led the "left opposition" to Hyndman and challenged the latter's leadership at every turn. Their breach with the S.D.F. was, in a large measure, the result of Hyndman's intrigues against Scheu's control of the semi-autonomous Scottish Land and Labour branch of the S.D.F. and Hyndman's accusation that Scheu was more an anarchist than a Socialist. Cf. Thompson, pp. 355, 396-97, 407-08; Tsuzuki, pp. 43, 58, 61, 64, 66; also Andreas Scheu, Umsturzkeime (n. p., 1920). 
Society, member of an individualist state, and therefore nobody's comrade. ${ }^{1}$

You inform me that the Committee have chosen my place as defender of the second resolution against possible opposition. If I may choose my own place, I shall prefer to provide the opposition myself. A composition of one hundred and thirty-odd words, utterly unintelligible to anyone not expert in Socialese, and missing the special point which makes the Soudanese war indefensible and atrocious even from the point of view of those who consider capitalism justified by the degree of civilisation which it imposes, does not deserve to be passed either by intelligent outsiders or adept Socialists.

As for Resolution I, you can hardly expect me to second or support a statement that war is, after all, "only the necessary outcome of commercial exploitation." The meeting will probably ask ironically "Oh, indeed! Is that all? Only the necessary outcome, forsooth." At least it would if it knew what commercial exploitation meant. But as a matter of fact the Egyptian war is a far lower form of villainy than commercial exploitation. The Socialists have unfortunately an unofficial explanation for all wars; and they have forced it upon this Egyptian affair with the result of considerably extenuating its wickedness.

On the whole I think I had better not speak. My position in the matter of war is that the ex-Khedive ${ }^{2}$ was a profligate, the bondholders his panderers and procuresses, the British army a catspaw, the British nation a fool, and the whole transaction an instructive epitome of human nature. I leave your denunciations, your sympathizings, your dauntless resistances, your curses, your glaring outgrowths, your victims planted in the soil and your commercial patriotism to be supported by Comrades Pecksniff, Chadband, and Joseph Surface. Damn your sentiments. Doubly damn your mixed metaphors.

Please apologize for my plainness to those members of the Council who are not my personal friends, and whose feelings I am therefore reluctant to hurt.

George Bernard Shaw

1 Dr. Letitia Fairfield, a long-time member of the Fabian Society and a friend of Shaw, relates that Shaw was always extraordinarily sensitive to being addressed "Comrade" Shaw. Conversation with Dr. L. Fairfield, Aug. 29, 1962.

2 A reference to the much maligned Ismael Pasha (1830-1895), khedive of Egypt from I 867 to 1879 . As a result of his extensive programme of reforms to benefit Egypt and the Sudan, Ismael bankrupted Egypt and he was compelled to submit his government's finances to Anglo-French control. In 1879, following a dispute with his English and French suzerains, Ismael was deposed from the khedivate. Cf. Richard Hill, A Biographical Dictionary of the Anglo-Egyptian Sudan (Oxford 1951), pp. 182-83. 
[Post card] [Shaw to H. Halliday Sparling] ${ }^{1}$

Wednesday, 2 ist October.

"The Division of Society into Classes"

by

George Bernard Shaw (Fabian Society) ${ }^{2}$

If at large! That is the ticket, sir.

GBS

[Post card]

[Shaw to Sparling]

\section{Dear Sparling}

36 Osnaburgh St. N.W. Ioth October 1885

Tonight at Morris's lecture I promised to speak at the Marylebone branch instead of Scheu on the 25 th inst. On opening my diary at that date I find that I am already down for the Woolwich Radical Club, and so must cry off Marylebone. Please tell Mainwaring ${ }^{3}$ I don't know his address. Excuse trouble.

Yrs.

George Ber etc etc etc

[Shaw to Sparling]

36 Osnaburgh St. N.W. I6th November I885

I am engaged to lecture at John St. Edgware Road on Sunday next, but as it is for the League, I suppose that can be arranged, in which case I am game for Leicester. ${ }^{4}$ But I should like the alteration to be announced as soon as possible, as I do not want to be stoned by a disappointed crowd of your worshippers.

${ }^{1}$ H. Halliday Sparling, the husband of Morris's daughter, May, replaced Mahon as Secretary of the Socialist League following Mahon's resignation from the League's Council in 1885 . Cf. Eshleman, p. 232 ; Thompson, p. 516.

2 See report of Shaw's lecture on "The Division of Society into Classes" at Farringdon Hall in The Commonweal, I (Nov. 1885), p. 100.

s Samuel Mainwaring, an engineer, was an early member of the Labour Emancipation League. A quiet and dignified man, he was involved in the pre-"Bloody Sunday" disturbances in November, I887, and remanded for trial at the Middlesex Sessions for "obstruction" in a public thoroughfare while speaking for the Socialist League. May Morris, II, p. 240; Thompson, pp. 41 2, 442.

4 Shaw's diary for Nov. 22, 188 \%, indicates that he lectured at Leicester. G.B.S. Diary, Jan. 1885 - July $31,1886$. 
I am sorry to hear that you have had such an unlucky bout of it this time. Those potatoes, I am told, should have been stolen in order to make the charm efficacious.

I have not got the address of Arnold, the Edgware Road secretary. Shall I write to Wade about it, or will you? As a rule my communications, oral or epistolary, only corrupt the League's good manners and produce no effect whatever. If Scheu is in town and disengaged, I have no doubt he would take my place. If not, Keddell ${ }^{1}$ has other Fabians to dispose of.

\section{GBS}

[Note in pencil by Sparling] See if Marylebone Branch can manage it, if not can Aveling go to Leicester instead of Shaw?

[Post card]

[Shaw to Sparling]

36 Osnaburgh St. N.W. 24th December I 885

George Bernard Shaw (Fabian serio-comic artist) at liberty for genteel leading business on the $13^{\text {th }}$ and $27^{\text {th }}$ prox. ${ }^{2}$ All other Wednesdays in January filled up.

\section{GBS}

[Post card]

[Shaw to Sparling]

36 Osnaburgh St. N.W. I4th February 1886

All right. Have booked you for Wednesday, 24th March, $\frac{1}{2}$ past 8 , at I 3 Farringdon Road. I have no subject ready. How would "Points disputed among Socialists" or "Variety of Opinion among Socialists" or "Points from which Socialist doctors differ" do? I want to let out a little about Communism. ${ }^{3}$

\section{[GBS]}

\footnotetext{
1 Frederick Keddell, a City clerk, was the first Secretary of the Fabian Society and a close friend of Hubert Bland. While most Fabians withdrew from the S.D.F. by January I 886, Keddell, remained with the Federation and later became its Treasurer. Tsuzuki, p. 72; Margaret Cole, The Story of Fabian Socialism(London i 961), pp. 5, 42n.

2 Entries in Shaw's diary for Jan. 13, I886, show that he "Made a speech at [the] Socialist League meeting [on] (The Political Outlook) at is Farringdon Rd..." On Jan. 27, he lectured at the same place on "Laissez Faire." G.B.S. Diary, Jan. I 885 - July 31 , i 886.

${ }^{3}$ Shaw was finally scheduled to speak on "Points disputed among Socialists." See The Commonweal, II (March, I886), p. 24.
} 
Dear Sparling 22nd February I 886

I have to lecture next Sunday for your Hoxton branch at Pitfield St. (Wherever that may be), and the subject has not yet been fixed. Kindly tell the lecture secretary, or whoever the proper official is, that I will hold forth on "The Unemployed."1

I saw you in the Park yesterday; but you were meditating profoundly; and would not respond to external stimuli.

$$
\text { G.B.S. }
$$

[Post card]

[Shaw to Sparling]

36 Osnaburgh St. N.W. 2nd June, i 886

All right. Can't make up my mind about the subject. Will let you know as soon as I have.

G.B.S.

[Post card]

[Shaw to Sparling]

36 Osnaburgh St. N.W.

I 3 th June, I 886

The title of my lecture on the $20 t h$ will be

"Socialism and Malthusianism""

I am going to show that Malthusianism is perfectly sound in relation to a system of property and that the ordinary Socialist attitude towards Malthusianism is

ASININE.

[GBS]

[Post card]

[Shaw to Sparling]

36 Osnaburgh St. N.W. I 8th August, I 886

I have booked "Why We Don't Act Up to Our Principles" for Wednesday the 22nd prox. at Farringdon Hall ${ }^{3}$ and "Thieves"

1 As he had indicated, Shaw lectured on "The Unemployed" to the Hoxton branch of the League on February 28. G.B.S. Diary, Jan. 1885 - July 31 , 1886.

2 The lecture was delivered as scheduled at Socialist League headquarters on Farringdon Road. Ibid.

3 Shaw's lecture at Farringdon Hall was evidently cancelled and he "spoke [instead] at Bendon Road..." Ibid., Aug. 1886-Nov. x 3, 1889. 
(confound it: I hate that lecture) for Sunday the 26 th at Herne Hill Working Man's Club. ${ }^{1}$ As I don't know where the latter is or how to get to it, they had better send me their address beforehand.

On receiving your last card, I wrote to Scheu, but he replied saying that I should not be at the concert.

$$
\text { G.B.S. }
$$

[Post card]

[Shaw to Sparling]

\section{Dear Sparling}

36 Osnaburgh St. N.W. 2 I st September, I 886

I find I have forgotten to answer your question about Goldwin Smith. ${ }^{2}$ If you are in a hurry for the review, No. If any time before next March will do, Yes. I can say no fairer than that.

$$
\text { G.B.S. }
$$

[Post card]

[Shaw to H. A. Barker] ${ }^{3}$

36 Osnaburgh St. N.W.

Dear Barker, 9 February, 1887

Excuse the formality of the enclosed. These things must be done solemnly.

\section{Yours,} GBS

[Shaw to Barker]

H. A. Barker

The Secy,

36 Osnaburgh St. N.W. $9^{\text {th February } 1887}$

The Socialist League

Dear Sir,

As a Socialist, I believe that it is time for us to abandon the principle of Individualism, and to substitute that of Socialism, on the pain of

1 There is no record in Shaw's diary of his appearance at Herne Hill on Aug. 26. Ibid.

2 Shaw's reply was in response to Sparling's request for a review of Goldwin Smith's pamphlet, False Hopes; or fallacies, socialistic and semi-socialistic, briefly answered (2nd ed., London I 886), 77 pp. A search of The Commonweal does not reveal that Shaw ever undertook the task.

${ }^{3}$ H. A. Barker, Sparling's successor as Secretary of the Socialist League, was a member of the "parliamentary" wing of the League. Cf. Thompson, p. 57I; Tsuzuki, p. 85. 
national decay. Holding this, I am bound to maintain it in open debate against anyone who disputes it and whose opinion to the contrary is of weight with the public. Therefore, though for formal reasons I am anxious to avoid any course that may strain the friendly relations which Mr. Bradlaugh's services to the people have established between him and my colleagues as well as myself, I cannot refuse to accept the duty of debating him if it be allotted to me by either of the ladies challenged by him. Only let it be understood, that I was not the challenger, and that I did not volunteer for the defence. ${ }^{1}$

As to the conditions of the debate, they may be left, as far as I am concerned, to the opposition. I should prefer an audience of undecided inquirers or individualists to one of convinced Socialists; and I had rather debate at a disadvantage than give my opponent the least cause to complain of the spirit in which he was met, or the manner in which the discussion was arranged.

I presume that your executive has duly weighed the fact that I am a member of the Fabian Society only, and am not bound by the Manifesto of the Socialist League. ${ }^{2}$

$$
\text { I am, dear Sir, }
$$

Yours faithfully,

\section{G. Bernard Shaw}

1 Since the Radical M. P., Charles Bradlaugh (1883-1891), had declared himself an uncompromising foe of Socialism in 1884, few within the Socialist fold were willing to attempt to match his oratorical skill in debate. But, early in 1887 , the Socialist League challenged Bradlaugh to a public debate and, in recognition of Shaw's prowess on the platform and a previous brush he had had with Bradlaugh, asked Shaw to represent the League in the contest with Bradlaugh. Shaw, however, was most reluctant to meet Bradlaugh and was quite relieved when the debate did not come off because of lack of agreement (which he tacitly encouraged) with Bradlaugh over the proposition and resolution to be debated. As Shaw later recalled: "I could not refuse the nomination in the face of the enemy, but I was greatly relieved when he imposed the condition, which I could not accept, that I should be bound by all the manifestoes of the Social Democratic Federation. The truth is, I was afraid of his enormous personal force, to which, at my age, I could make no pretension." Shaw's letter to the Editor published as "George Bernard Shaw and the National Secular Society" in The Freethinker, Oct. 13, 1920, as reprinted in Champion of Liberty: Charles Bradlaugh (Centenary Volume) (London 1933), p. 50; see also Thompson, pp. 307, 585 \& n.; Henderson, Shaw. Playboy and Prophet, p. 168; Henderson, Shaw: Man of the Century, p. 228.

2 Apparently a reference to the "New Manifesto of the Socialist League," issued in early 188 s, which differed slightly from the League's first manifesto calling for militant revolutionary Socialism. Cf. Eshleman, pp. 249-50. 
[Post card]

[Shaw to Barker]

36 Osnaburgh St. N.W. I I th February, I 887

My reply to your letter was posted yesterday, early in the afternoon. G.B.S.

[Shaw to Barker]

36 Osnaburgh St. N.W. 24th February, I887

To the Secretary of the Socialist League

\section{Dear Sir}

I am afraid I should mislead Mr. Bradlaugh if I were to accept, as he requires, the manifestoes of the Democratic Federation and Socialist League. I do not mind saying that they are defensible and wholesome documents; but I have just an article by Mr. Bradlaugh in "Our Corner" 1 which convinces me that if I undertake to be bound by them, the debate will be wasted in disputes as to what they mean. If the debate is to be on the manifestoes, then Mr. Bradlaugh must challenge them; express his opinion of them in a proposition; and offer to maintain the proposition against anyone who will undertake to defend the manifestoes. Whether I would undertake such a defence would of course depend on the terms of the proposition. In any case, Mr. Bradlaugh would have to assume the offensive and open the debate.

But if I am to challenge the validity of the principle of individualism, and $\mathrm{Mr}$. Bradlaugh to defend it, then I will be bound by nothing except the terms of the proposition and my controversial duties. In order to leave no doubt that my attack on individualism commits me to the advocacy of the proposals concerning land and capital which make socialism practically revolutionary, I will affirm "That it is advisable to abandon the principle of individualism for that of socialism; and that this change of policy can be made effective only by the complete resumption of the land, with a transfer of existing capital of the country from its present holders to the state?" If this does not commit me deeply enough, I must leave it to Mr. Bradlaugh to state explicitly what further inference from the manifestoes he will expect me to adopt.

1 Cf. Charles Bradlaugh, Socialism: Its Fallacies and Dangers, in: Our Corner, IX (March I, I 887), pp. 129-36. 
If this seems unfair, kindly write to me before communicating with Mr. Bradlaugh. I do not wish to raise difficulties - only to avoid misunderstanding as far as I can.

I am, dear Sir

Yours faithfully

G. Bernard Shaw

[Shaw to Barker]

The Secretary

29 Fitzroy Square W.

Socialist League

\section{Dear Sir}

I have read the letter from Mr. Bradlaugh which you forwarded to me. I have only to say, in the friendliest spirit, that I also see no reason to modify my last letter in any respect.

I am, dear Sir

Yours faithfully, G. Bernard Shaw

[Post card]

[Shaw to Barker]

Dear Barker

29 Fitzroy Square W. I 8 th May, i 887

I had no intention of speaking at Victoria Park. Mrs. Besant ${ }^{1}$ will be there to represent the Fabian [Society], I believe; and I don't see that I am indispensable to the success of the meeting. Are there not millions of Radicals all foaming at the mouth on the job? If I have nothing else to do I will go; and if I speak, I had just as soon - or rather - speak from the League platform ${ }^{2}$ as anywhere else; but I am not a bit excited over it.

$$
\text { G.B.S. }
$$

1 Mrs. Annie Besant (1847-1933), an intimate friend of Bradlaugh, Shaw, and W. T. Stead. She was a close collaborator of Bradlaugh in the National Secular Society until she joined the Fabian Society in 1885 . At this time, she was editor of the periodical, Our Corner, which served as an organ for the dissemination of the views, opinions, and work of both Bradlaugh and Shaw. On the life and career of Mrs. Besant and her relationship with Bradlaugh and Shaw, see her Autobiography (London I 893); Arthur Nethercot, The First Five Lives of Annie Besant (Chicago 1960), passim.

2 Shaw spoke from the Socialist League platform at Victoria Park on May 2I, in the company of Mrs. Besant. G.B.S. Diary, Aug. I 886 - Nov. I 3, 1889. 
[Post card]

[Shaw to Barker]

29 Fitzroy Square W. 28th August I 887

Dear Barker

Perform at a concert! I am surprised at you. You know I can't do these things. The Commonweal ought to be ashamed of itself. Let it just make me editor at ro guineas a week; and you will soon be giving free concerts, with refreshments included, out of the profits.

$$
\text { G.B.S. }
$$

[Shaw to Barker]

29 Fitzroy Sq. W. 26th October, 1887

\section{Dear Barker}

Eight and four pence enclosed for my share of the expenses of the meeting at South Place, ${ }^{1}$ as per your lucid account.

Yours

\section{GBS}

1 The entry in Shaw's diary for Oct. 14, 1887 records that he „Spoke at [the]Free Speech Meeting at South Place [Institute] for [the] release of [the] Chicago Anarchists..." tried for alleged charges of conspiracy and terrorism in the Haymarket riot of early May, 1886 in Chicago. G.B.S. Diary, Aug. 1886-Nov. 13, 1889. Four of the accused were hanged in November, 1887, one committed suicide in prison, two had their death sentence commuted to life imprisonment, and one was sentenced to gaol for fifteen years. Those imprisoned were later pardoned by Governor Peter Altgeld in 1893. 